\title{
PENATALAYANAN GEREJA DI BIDANG MISI SEBAGAI KONTRIBUSI BAGI PELAKSANAAN MISI GEREJA
}

\author{
Ramona Vera Amiman
}

\section{PENDAHULUAN}

Di dalam seluruh isi Alkitab disaksikan bahwa Allah mengutus banyak orang "menjalankan misi dari Allah". Misi itu muncul dari hati Allah sendiri, lalu dikomunikasikan kepada hati umat-Nya, dan karena Allah ingin menjangkau umat manusia secara global, maka Allah memanggil dan mengutus gereja-Nya untuk melaksanakan misi-Nya. Pelaksanaan misi Allah itu bukan hanya berupa misi penginjilan secara lintas budaya saja, tetapi segala sesuatu yang menjadi jatidiri, baik yang dikatakan maupun yang dilakukan seorang Kristen dan sebuah Jemaat Kristen, semestinya bersifat missioner. Karena misi gereja itu mengalir dari misi Allah, dan misi Allah ada demi seluruh dunia milik-Nya, maka gereja harus mulai dengan melihat bahwa dirinya berada dalam aliran besar misi Allah, gereja mesti memastikan bahwa sasaran-sasaran missionernya, baik yang jangka panjang maupun pendek, bersesuaian dengan sasaran Allah. Itulah sebabnya sangatlah penting bagi gereja untuk melaksanakan misi, karena apabila gereja tidak melakukan misi maka gereja akan sulit bertumbuh dan berkembang, yang pada akhirnya gereja mengalami kemunduran.

Tujuan gereja adalah melakukan misi Allah, menghadirkan damai sejahtera Allah di tengah-tengah dunia. Misi tersebut terkandung dalam tri tugas panggilan gereja, yakni: bersekutu (koinonia), bersaksi (marturia), dan melayani (diakonia). Agar gereja dapat melakukan pelayanan misi di tengah-tengah dunia ini, maka gereja harus melakukan penatalayanan bagi pelayanan gereja itu sendiri, karena penatalayanan merupakan tanggung jawab gereja. Karena penatalayanan berhubungan dengan tugas dan tanggung jawab, maka dalam melakukan penatalayanannya, gereja melaksanakan pekerjaan Allah yang telah dimandatkan kepadanya dan sepenuhnya melayani atas nama Allah serta bertanggung jawab kepada Allah atas pelaksanaan semua pekerjaan yang ditanggung atasnya. Tanggung jawab dalam melakukan penatalayanan ini merupakan bagian penting dalam gereja.

Penatalayanan juga adalah pokok yang penting dalam pelayanan gereja, karena penatalayanan berkenaan dengan pengelolaan semua sumber daya yang telah dipercayakan Allah kepada gereja. Segala sesuatu adalah milik-Nya, tetapi Dia telah menunjuk gereja sebagai penjaga milik-Nya, Maka gereja bebas mengatur semua sumber daya itu, tetapi pada akhirnya nanti harus dipertanggungjawabkan kepada-Nya sesuai dengan garis-garis pedoman yang terdapat dalam Alkitab. 


\section{Penatalayanan Gereja}

Berkaitan dengan penatalayanan gereja, maka peneliti akan mengemukanan tentang pengertian penatalayanan, dasar Alkitab bagi penatalayanan Kristen, Penatalayanan Gereja, Lingkup Penatalayanan Kristen, subyek penatalayanan gereja, serta kewajiban dan tanggung jawab penatalayanan gereja.

\section{Pengertian Penatalayanan}

Pada awal penciptaan, Allah memanggil manusia untuk bertanggung jawab atas bumi dan segala isinya. Tanggung jawab yang besar ini merupakan anugerah yang diberikan oleh Allah, dan diberikan secara gratis. Peranan manusia, bukanlah sebagai pemilik maupun penguasa atas bumi dan segala isinya, melainkan sebagai seorang hamba/ pekerja yang diberikan tanggung jawab untuk mengatur dan mengelola pemberian dari tuannya. Menurut M.L. Cooper White, penatalayanan tidaklah semata mata berkaitan (terutama) dengan uang maupun barang. Pelaksanaan penatalayanan diikuti oleh spiritualitas, dalam artian bahwa pelaksanaan penatalayanan disertai dengan memikul salib Tuhan. ${ }^{1}$ Pelaksanaan penatalayanan yang berlangsung seringkali keluar dari identitas kita sebagai murid Tuhan. Hidup dalam jalan yang seperti ini adalah sebuah proses yang dengan sengaja akan membawa kita memilih untuk melawan setiap tantangan. Maka dari itu Cooper White mengatakan bahwa penatalayanan harus didasari dengan spiritualitas.

\section{Penatalayanan Dalam Perjanjian Lama}

Penggunaan istilah penatalayanan dalam Perjanjian Lama artinya kepala rumah tangga (Ibrani: ha ish asher al) dalam Kejadian 43:19, atau kepala rumah dalam Kejadian 44:4 (Ibrani: asher al bayith) yang artinya orang yang kepadanya dipercayakan tanggung jawab dan tugas untuk mengepalai serta mengurus harta serta segala kegiatan di dalam rumah tangga. ${ }^{2}$ Istilah lain yang ada hubungan arti dengan ini ialah hamba yang lahir di dalam rumah tuannya, yang diterima dan memperoleh hak sebagai pewaris yang terdapat dalam Kejadian 15: 3 - 4 (Ibrani: ben mesheq). Disamping itu, terdapat juga istilah sar (Ibrani) yang artinya orang yang melayani (1 Tawarikh 28:1) dalam kedudukan sebagai pangeran atau kapten (kepala pasukan). ${ }^{3}$ Melalui pengertian di atas, dapat dijelaskan bahwa penatalayan adalah orang yang dipercayai dan diberi hak serta tanggung jawab untuk mengepalai, mengatur dan mengerjakan segala sesuatu yang dipercayakan kepadanya. ${ }^{4}$ Penatalayan memiliki status sebagai pelaksana yang memiliki hak serta kewajiban, yang didalamnya terdapat tanggung jawab terhadap tugas yang diberikan kepadanya, yang bertujuan untuk menjalankan pengabdiannya kepada pemimpinnya atau tuannya atau pemilik.

${ }^{1}$ Michael L. Cooper White, "Christian Stewardship In The Light Of A Theology Of The Cross", (Dialog: A Journal of Theology 48 (2009)

${ }^{2}$ Y. Tomatala. Penatalayanan Gereja ..., 11

${ }^{3}$ Ibid., 11

${ }^{4}$ Ibid., 11 


\section{Penatalayanan Dalam Perjanjian Baru}

Dalam Perjanjian Baru, kata penatalayanan berasal dari kata oikonomos (Yunani), yang terdiri dari dua kata, yakni oikos artinya rumah dan nemo artinya mengurus. Dalam dunia Yunani kuno kata oikonomos memiliki banyak makna, tetapi mengarah kepada administrasi atau manajemen rumah tangga, yang menerangkan tentang seseorang yang kepadanya telah dipercayakan tanggung jawab penuh. ${ }^{5}$ Oikonomos, kemudian diterjemahkan sebagai stewardship dalam bahasa Inggris, yang mempunyai arti tanggung jawab yang dipercayakan untuk mengurus segala urusan rumah tangga. Kata stewardship sering diartikan sebagai seorang hamba yang diberikan tanggung jawab atas uang, harta, barang-barang maupun sumber daya manusia. Jadi kata ini membawa ide, bahwa seorang pemilik/tuan yang memberikan kepercayaan serta tanggung jawab kepada seseorang/hamba untuk mengurus suatu kepemilikannya. ${ }^{6}$ Surat-surat para rasul menggunakan istilah oikonomos untuk menyebut para pelayan Kristus. Dalam I Korintus 4:1,2, rasul Paulus menyebut dirinya dan teman-teman sekerjanya sebagai penatalayan rahasia Allah. Kemudian dalam Titus 1:7, Paulus menyebut penilik jemaat sebagai penatalayan Allah. Rasul Petrus dalam I Petrus 4:10 menganggap dirinya dan orangorang Kristen sebagai penatalayan kasih karunia Allah. ${ }^{7}$ Selain kata oikonomos, dalam Perjanjian Baru juga terdapat kata lainnya yakni epitropos (Matius 20:8, Lukas 8:3, Galatia 4:2) yang dipakai untuk menggambarkan seseorang yang berfungsi dalam penatalayanan. Epitropos menjelaskan tentang seseorang yang mendapat kehormatan dan kepercayaan untuk melaksanakan suatu tugas tertentu. ${ }^{8}$ Dalam terjemahan baru LAI, kata tersebut diartikan dengan mandor, bendahara dan wali. Epitropos dimaksudkan untuk menjelaskan tentang seseorang yang dipercayakan atau diamanatkan sebuah tanggung jawab. Yesus secara tegas menggambarkan penatalayan sebagai bagian utuh dari tujuan kedatangan-Nya dengan mengatakan, "Anak manusia yang datang bukan untuk dilayani, melainkan untuk melayani dan untuk memberikan nyawa-Nya menjadi tebusan bagi banyak orang" (Markus 10:45). Yesus menyampaikan bahwa tugas pelayanan yang sedang dilaksanakan adalah tugas yang diterima dari Bapa (Yohanes 7:16-18, 6;37-40, 12:49-50). Tugas ini merupakan suatu tanggung jawab dan kepercayaan Bapa kepada-Nya, yang harus dilaksanakan secara menyeluruh dan penuh tanggung jawab. ${ }^{9}$

Berdasarkan penjelasan diatas, maka penatalayan dalam Perjanjian Baru berarti seseorang yang mendapat kehormatan dan kepercayaan, berdasarkan pada pendelegasian tugas dan wewenang yang penuh untuk melaksanakan suatu pekerjaan khusus yang dipercayakan kepadanya. Sedangkan penatalayanan lebih berhubungan dengan tugas dan

\footnotetext{
${ }^{5}$ Y. Tomatala, Penatalayanan Gereja..., 11

${ }^{6}$ Richard B. Cunningham, Creative Stewardship, (Nashville: Abingdon Press, 1989), 17.

${ }^{7}$ M.S. Anwari, Peranan Penatalayanan Dalam Pengembangan Jemaat, (Malang: Gandum Mas,

${ }^{8}$ Y. Tomatala, Penatalayanan Gereja..., 11

${ }^{9}$ Y. Tomatala, Penatalayanan Gereja ..., 12 - 16.
} 2002), 7. 
aturan-aturan yang dibuat untuk mendukung pelaksanaan tugas tersebut. ${ }^{10}$

\section{Penatalayanan Gereja}

Sebagai satu persekutuan orang yang beriman, maka yang harus dilihat dari gereja ialah adanya "tertib" yang dituangkan dalan "tata". Keteraturan itu diwujudkan dalam penatalayanan gereja yang terkadang tidak sedikit yang meributkannya, dan banyak yang menganggap sebagai sesuatu yang tidak penting. Tapi sesungguhnya tanpa penatalayanan, maka pelayanan gereja yang baik akan sulit terwujud. Sehingga sebagaimana setiap tindakan memiliki dasar untuk melakukannya, visi bisa tercapai dengan rumusan misi yang terarah, demikian pulalah dalam pelayanan gereja terhadap jemaat dan dunia, sebagai pengejawantahan panggilan hidupnya, maka penatalayananlah sebagai pondasi gereja. 11

Penatalayanan ketika dipahami secara benar, maka akan menyediakan sebuah model yang unik untuk hidup kreatif. Penatalayanan adalah kunci untuk menafsirkan dan mengintegrasikan berbagai dimensi kehidupan individu dan kehidupan gereja dalam pelayanan. Penatalayanan adalah tanggung jawab manusia dihadapan Allah untuk hidup dalam kehendak Allah sebagaimana yang terungkap dalam diri Yesus.

Gereja merupakan sebuah komunitas penatalayanan dalam tujuan utama Allah dalam sejarah manusia. Gereja mewakili permulaan dari manusia baru yang dipanggil oleh Allah. Gereja adalah gambaran keluarga Allah yang menyediakan titik awal yang konstruktif untuk memahami penatalayanan gereja terhadap: sumber daya manusia, spiritual dan materi dalam pelayanan Tuhan. Seluruh penatalayanan dalam gereja mengenai sumber dayanya harus berkontribusi pada peneguhan dan menyatukan gereja, sebagai persiapan bagi pelayanan dan misi di dunia. ${ }^{12}$

Ukuran besaran tanggungjawab penatalayanan, akan terlihat melalui seberapa baik gereja mewujudkannya dalam praktek teologinya dan misi gereja. Penatalayanan Gereja mengandung makna bahwa gereja melalui para warga jemaatnya, diberikan kepercayaan dan mendapat kehormatan untuk mengepalai dan mengatur serta mengerjakan tugas pelayanan Kristus yang telah dimandatkan secara penuh.

Tuhan Yesus berbicara banyak mengenai penatalayanan dan Ia memperkenalkan prinsip - prinsip penatalayanan dengan jelas. Sejalan dengan itu, penatalayanan menunjukkan tanggungjawab manusia atas segala sesuatu yang Allah berikan di dunia ini. Akan tetapi dipihak lain, Allah sebagai pemilik mutlak itu memberikan kepada manusia wewenang penuh untuk membangun, mengusahakan dan menyelenggarakan apa yang telah Ia sediakan. Dengan kata lain, Allah tidak hanya memanggil manusia untuk melakukan penatalayanan, tetapi serentak dengan itu Ia juga memanggil manusia untuk bekerjasama dengan Dia. Melalui hal ini, gereja dipanggil untuk menjalankan tanggung-jawabnya sebagai penatalayan dengan memberdayakan, memanfaatkan, mengelola, dan memperbanyak setiap sumber daya yang dimiliki, untuk pelaksanaan

\footnotetext{
${ }^{10}$ Ibid., 12

${ }^{11}$ George Barna. The Habits of Highly Efective Churches..., 152-153

${ }^{12}$ Richard B. Cunningham, Creative Stewardship ..., $111-112$
} 
pelayanan dan kesaksiannya di dalam dunia ini. ${ }^{13}$

Maka penatalayanan Gereja yang patut dan membawa kemajuan bagi perkembangan gereja haruslah seperti yang telah dilaksanakan oleh Tuhan Yesus Kristus sebagai "Penatalayan Agung". Yesus Kristus telah melengkapi gereja dengan karuniakarunia rohani untuk pelaksanaan penatalayanan Allah di dalam dan melalui gereja. ${ }^{14}$

Beberapa kesimpulan tentang penatalayanan Gereja sebagai berikut:

1) Penatalayanan Gereja adalah penatalayanan Allah yang bertujuan untuk membangun Tubuh Kristus (Gereja) demi kepentingan bersama.

2) Setiap orang Kristen adalah penatalayan Allah yang harus terlibat dalam penatalayanan Gereja.

3) Allah telah menganugerahkan karunia rohani untuk melakukan tugas dalam penatalayanan Gereja, jadi tidak ada alasan bagi orang Kristen untuk mendalihkan diri, karena potensi untuk penatalayanan Gereja telah diberikan oleh Roh Kudus kepada semua orang Kristen di dalam gereja, dan karena itulah mereka harus menatalayani.

4) Karunia rohani yang diberikan Allah dalam melengkapi orang Kristen untuk penatalayanan berbeda bagi setiap orang, tetapi mempunyai tujuan yang satu, yaitu membangun Tubuh Kristus. Setiap orang Kristen patut mengorbankan diri (demi kasih) untuk terlaksananya penatalayanan Allah yang ditanggungkan atas Gereja. ${ }^{15}$

Semua penatalayanan Kristen haruslah dilakukan dengan kesadaran bahwa penatalayanan Kristen adalah kepercayaan dari Allah untuk Gereja menatalayani pekerjaan-Nya. Dalam pelaksanaanya, penatalayanan gereja berpedoman pada penatalayanan yang dilakukan oleh Yesus Kristus. Penatalayanan gereja bertujuan untuk membangun tubuh Kristus dan mewujudkan missio dei.

Maka gereja harus memotivasi jemaat untuk hidup sebagai penatalayan yang efektif, memfokuskan jemaat pada gambaran kehidupan kristiani dengan memperluas pandangan jemaat terhadap penatalayanan, agar mampu mengelola sumber daya, sehingga jemaat lebih mengenali iman mereka, lebih taat kepada Allah melalui praktik penatalayanan, dan gereja menjadi alat perubahan yang efektif. ${ }^{16}$

\section{Subyek Penatalayanan Gereja}

Perlu ditegaskan bahwa peran gereja sebagai lembaga itu tidak menggantikan peran pribadi warga gereja dalam menatalayani. Setiap warga gereja harus berperan ganda. Artinya, secara pribadi menjadi menatalayani dalam jemaat dan masyarakat serta bersama-sama dengan warga gereja lainnya harus menatalayani pekerjaan Tuhan di dalam jemaat dan masyarakatnya. ${ }^{17}$

\footnotetext{
${ }^{13}$ repository.uksw.edu>bitstream. diakses 23 April 2018

${ }^{14}$ Y. Tomatala. Penatalayanan Gereja..., 18

${ }^{15}$ Y. Tomatala. Penatalayanan Gereja..., 18-19

${ }^{16}$ George Barna. The Habits of Highly Efective Churches..., 164

${ }^{17}$ https://spwgblog.wordpress.com. diakses 15 Oktober 2017
} 
Sasaran pekerjaan Allah yang besar ini adalah seluruh umat manusia dan dunia. Yesus adalah teladan orang Kristen dalam menatalayani sebab la datang untuk melayani, bukan untuk dilayani (Mrk. 10:45).

Kelak Tuhan meminta setiap orang Kristen mempertanggungjawabkan waktunya, hartanya, kemampuannya dan lainnya. "Demikianlah setiap orang di antara kita akan memberi pertanggunganjawab tentang dirinya sendiri kepada Allah" (Rm.14:12). Orang Kristen juga harus mewaspadai godaan dalam menatalayani. Di antaranya, godaan memakai waktu, harta, kepandaian untuk kesukaan dan kenikmatan dirinya sendiri. ${ }^{18}$

\section{Kewajiban Dan Tanggung Jawab Penatalayanan Gereja}

Kita mengakui bahwa Allah mahatinggi. Pengakuan itu harus menjadi "darah daging" kita. Artinya, pengakuan itu harus menjadi motivasi, mewarnai pikiran, kehendak dan perilaku kita sebagai ucapan syukur kepada Tuhan. Allah menghendaki supaya kita bertumbuh mengejar kedewasaan Kristen. Salah satu ciri dalam proses menjadi dewasa itu ialah tanggung jawab. ${ }^{19}$

Tuhan menghendaki supaya kita menjadi hamba-hamba-Nya yang taat kepadaNya. Wujud nyata dari ketaatan itu ialah kesediaan kita untuk bekerja melayani sesama manusia dengan menggunakan talenta yang kita terima. Allah telah menyiapkan pekerjaan yang baik buat kita (Ef. 2:10). Dalam menatalayani, maka motivasi (dorongan) sangat penting. Motivasi itu menentukan semangat, suasana dan seringkali hasil-hasilnya. Motivasi yang benar dilandasi dengan: Rasa syukur dan mengasihi Tuhan karena Dia telah lebih dahulu mengasihi kita. Siapa yang benarbenar mengasihi Tuhan pasti mengasihi sesamanya baik dengan perkataan, perbuatan maupun kebenaran (1Yoh. 3:18). Memuliakan Allah dalam segala sesuatu karena Yesus Kristus yang empunya kemuliaan dan kuasa selama-lamanya (1Ptr. 4:10-11) ${ }^{20}$

Oleh sebab itu gereja harus bekerja keras untuk memasukkan konsep penatalayanan ke dalam berbagai pelajaran / pengajaran yang diajarkan di gereja, karena dengan memasukkan konsep-konsep penatalayanan dalam pelajaran yang diajarkan, maka jemaat tidak hanya diingatkan akan luasnya serta pentingnya penatalayanan, tetapi juga diperhadapkan pada cara-cara untuk saling menghubungkan pandangan pemikiran dan kehidupan iman yang pokok dalam cara hidup Kristen secara menyeluruh. ${ }^{21}$

Beberapa alasan mengapa gereja membutuhkan peraturan-peraturan bagi pelayanan misi, yaitu:

1) Untuk menolong gereja/jemaat memiliki arah yang jelas bagi hubungan program pelayanan misi dengan pelayanan keseluruhan dari gereja.

2) Untuk menolong gereja/jemaat agar tidak membuat keputusan-keputusan secara emosional atau berbahaya karena kurang berhati-hati.

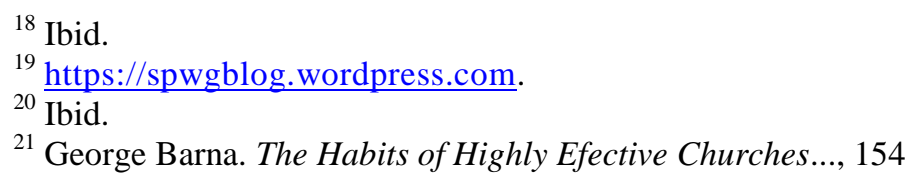

${ }^{18}$ Ibid.

${ }^{19} \mathrm{https}: / /$ spwgblog.wordpress.com.

${ }^{20}$ Ibid.

${ }^{21}$ George Barna. The Habits of Highly Efective Churches..., 154 
3) Untuk menolong agar lebih bijaksana dalam penggunaan uang, sehingga memungkinkan para pemimpin gereja menjadi penatalayan yang baik atas uang Tuhan.

4) Agar anggota komisi mendapat pengenalan yang lengkap tentang program misi gereja.

5) Akan memelihara konsistensi dan kelanjutan visi misi dalam gereja meskipun ada pergantian anggota-anggota komisi misi dan pimpinan.

6) Untuk menghemat waktu dan diskusi karena banyak hal sudah digariskan dalam peraturan tersebut.

7) Akan memberikan petunjuk dalam mengevaluasi, baik pengurus, calon-calon pelayan misi, bagaimana mendukung pelayanan misi (program-program dan orang-orang), dan pembinaan/pendidikan misi secara menyeluruh bagi gereja. ${ }^{22}$

Dengan memiliki peraturan tersebut pelayanan misi yang tertulis dan diterapkan dengan baik, akan sangat menghemat banyak waktu dan menghindar dari simpang siurnya penatalayanan gereja.

Dengan semua yang di kemukakan di atas, diharapkan gereja/orang kristen dapat hidup secara bertanggung jawab dalam setiap waktu pada setiap konteks, dan mampu merefleksikan imannya secara relefan dalam kata dan tindakan.

\section{Misi Gereja}

Konsep misi gereja perlu digali kembali dengan pertama-tama menafsirkan secara utuh apa yang sebenarnya dimaksudkan dengan misi Allah menurut kesaksian Alkitab, karena keberadaan dan misi gereja itu bertitik tolak dari misi Allah. Seperti yang dikatakan oleh Widi Artanto: Gereja pada dirinya sendiri tidak punya misi karena misi gereja adalah terlibat dalam misi Allah di tengah-tengah dunia ini. Gereja ada karena Misi Allah dan hidup dalam Misi Allah, serta dipanggil untuk melaksanakan dan melanjutkan Misi Allah di tengah-tengah dunia ini. Karena itu, gereja tidak dapat dipisahkan dari misi Allah, misi yang bukan sekedar salah satu dari tugas gereja, yang dapat dilakukan dengan sepenuh atau setengah hati, melainkan misi yang adalah hakikat gereja itu sendiri. ${ }^{23}$

Misi gereja adalah bertanggung jawab pada pelayanan penginjilan dan keterlibatan dalam bidang sosial politik. Keduanya adalah tugas gereja dalam mengekspresikan totalitas kasih dan tanggung jawab pribadi dan sosial gereja kepada sesama dan ketaatan kepada Yesus Kristus. Satu pemahaman bahwa misi adalah tugas eksklusif yang diberikan Allah kepada gereja/orang-orang yang percaya kepada Yesus, yang melalui gereja-Nya Allah mempedulikan hidup manusia dalam segala dimensi kehidupan (sosial, ekonomi, politik, keamanan, keadilan, dsb). Gereja diutus oleh Tuhan Yesus berdasarkan pola pengutusan-Nya sendiri: “...sama seperti Bapa mengutus Aku,

${ }^{22}$ Keith E. Brown. Pelayanan Misi Dalam Gereja-Gereja Lokal di Asia. (Batu: Departemen Misi YPPII), 59

${ }^{23}$ Widi Artanto, Gereja dan Misi-Nya, (Yogyakarta: Yayasan Taman Pustaka Kristen Indonesia, 2016) 6 
demikian juga sekarang Aku mengutus kamu" (Yoh. 20:21, band. 17:18). Ketaatan gereja dalam pelaksanaan misi ini adalah bergantung pada ketaatan gereja kepada Pengutus, yaitu Yesus Kristus (Missio Christi). ${ }^{24}$ Dengan demikian sebagai utusan, gereja tidak bisa berperan lain selain berperan sebagai instrument utusan Kristus, yang berperan menyaksikan Kristus, memberitakan kabar baik kepada semua orang. Persekutuan kita dengan Allah terjalin dalam cinta kasih dan ketaatan. Allah akan bersukacita bila kita sebagai ciptaan baru Allah didalam Yesus Kristus, melaksanakan misi Allah dengan iman dan kasih, untuk melayani dunia.

Untuk memahami mengenai misi gereja dalam terang misi Allah, maka haruslah dimengerti apa hakikat gereja, hakikat dari gereja Yesus Kristus. Untuk itu penulis akan menguraikan tentang apa itu misi dan apa itu gereja secara terpisah.

\section{Misi}

Istilah Misi (Mission) berasal dari bahasa Latin Missio dengan kata dasar Mittere yang berkaitan dengan kata Missum yang artinya mengirim/mengutus, "act of sending, being sent or delegated bay authority/persons sent, etc". ${ }^{25}$ Jadi misi adalah berkenaan dengan tindakan pengutusan, bahwa seseorang diutus dengan penuh otoritas pengutus untuk melaksanakan tugas tertentu. Berpadanan dengan pengertian diatas, adalah kata dalam bahasa Yunani "appostello". Kata Appostello ini tidak berarti mengirim/kirim (ретро) secara umum, melainkan mengirim dalam pengertian khusus, yaitu mengirim dengan otoritas. Dalam hal ini, yang dikirim atau yang diutus dengan otoritas itu untuk tujuan khusus yang akan dicapai. ${ }^{26}$

Misi, Missio Dei, Missio Ecclesiae: adalah akar kata misi dalam pengutusan (dari bhs. Inggris Mission yang berasal dari bhs. Latin Mitto). Dalam abad ke-20 semakin dimengerti bahwa dasar misi secara alkitabiah bukanlah misi gereja (Missio Ecclesiae), melainkan Misi Allah (Missio Dei) yang menyeluruh kepada dunia, dan yang tampak dalam Alkitab dari kitab Kejadian sampai Wahyu. ${ }^{27}$ Dalam Kamus Besar Bahasa Indonesia (KBBI), kata misi diartikan sebagai kegiatan menyebarkan Kabar Gembira (Injil) dan mendirikan jemaat setempat, dilakukan atas dasar pengutusan sebagai kelanjutan misi Kristus. Sedangkan kata Misioner berarti bersifat misi (KBBI) ${ }^{28}$ Tetapi, berkaitan dengan misi lintas budaya abad-abad lalu, misi dan missioner sering dikaitkan hanya dengan misi ke tempat yang jauh (Bnd. Misionaris - bhs Inggris Missionary), padahal seluruh jemaat/gereja seharusnya missioner, dalam arti semuanya dimobilisasi dan diutus ke dalam dunia menjadi terang dan saksi di mana saja melalui perbuatan dan perkataan. ${ }^{29}$

${ }^{24}$ Stevri I.Lumintang, Misiologia Kontemporer..., 55

${ }^{25}$ Y. Tomatala, Teologi Misi. (Jakarta: YTb Leadership Foundation, 2003). 16

${ }^{26}$ David J. Bosch, Trasformasi Misi Kristen (Jakarta: BPK Gunung Mulia, 1997). 1

${ }^{27}$ John Ruck, dkk, Jemaat Misioner. (Jakarta: Yayasan Komunikasi Bina Kasih, 2011) 20

28 __ Kamus Besar Bahasa Indonesi, Pusat Bahasa, (Jakart: PT. Gramedia Pustaka Utama, 2012)

\footnotetext{
${ }^{29}$ John Ruck, dkk, Jemaat Misioner..., 20
} 
Secara teologis, misi Allah tidak pernah berubah, karena misi berangkat dari hakekat Allah yang tidak dapat berubah. Ketidak berubahan misi Allah termanifestasi dalam kuasa-Nya yang telah, sedang dan terus mengubah dunia. ${ }^{30}$

\section{Misi Dalam Perjanjian Lama}

Yang diutamakan dalam Perjanjian Lama adalah pemilihan Allah atas Israel, dan hubungan antara Israel dengan bangsa-bangsa. Pemilihan Israel yang berakar pada pemilihan Allah atas Abraham sebagai yang khusus untuk melaksanakan misi Allah untuk dunia. Abraham dipilih sebagai orang yang dibenarkan oleh iman, dan dipilih untuk menjadi alat dalam dunia (Kej.12:1-30) ${ }^{31}$ Dalam rencana dan maksud Allah, Israel selalu bertanggung jawab untuk menyampaikan kabar tentang kasih karunia Allah kepada bangsa-bangsa lain. Israel dimaksudkan sebagai bangsa yang menyampaikan firman. ${ }^{32}$ Untuk itu mari kita lihat pendapat ahli mengenai pemilihan Israel, dalam konteks misi, yaitu, menurut Dr. Arie De Kuiper, ada tiga aspek yang perlu diperhatikan dari pemilihan Israel, yaitu:

a) Aspek Universalisme.

Dari halaman pertama Kitab Suci, sudah diperhadapkan dengan perbuatanperbuatan Allah terhadap seluruh dunia. Ia bertindak secara universal. Kisah penciptaaan langit dan bumi dan penempatan manusia di dalamnya merupakan prasejarah bagi Israel, dan serentak pula prasejarah bagi sejarah keselamatan untuk seluruh dunia. Kej. 1 s/d 11 adalah pendahuluan dan latar belakang dari sejarah Israel selanjutnya. Sifatnya sangat universal. Perhatian diarahkan kepada segenap umat manusia. Tetapi prasejarah ini juga memperlihatkan bagaimana dosa masuk ke dalam dunia. Keadaan yang demikianlah yang menjadi latar belakang pemanggilan Abram (Kej. 12), untuk pergi dari sanak saudaranya, meninggalkan dunia orang kafir. Dan Tuhan berjanji bahwa ia "akan menjadi berkat" bagi semua kaum di muka bumi. ${ }^{33}$

Kisah pemilihan Abraham dan keturunannya merupakan persiapan bagi pemilihan Israel yang berwujud "keluaran" dari Mesir. Dengan memilih umat Israel, maka Allah mengarahkan pandangan-Nya kepada seluruh dunia. Dalam hubungan ini, maka pentinglah kata-kata Keluaran 19:5-6: “... kamu akan menjadi harta kesayanganKu sendiri dari antara segala bangsa, sebab Akulah yang empunya seluruh bumi. Kamu akan menjadi bagiKu kerajaan imam dan bangsa yang kudus". Kekudusan dan keimaman menyatakan fungsi pelayanan. Selaku pengantara, Israel melayani juga bangsa-bangsa (Yes.61:6). ${ }^{34}$

\footnotetext{
${ }^{30}$ Stevri I. Lumintang. Misiologia Kontemporer... 17-18

${ }^{31}$ David J. Bosch, Trasformasi Misi Kristen ..., 627-629

32 John Stott, Johannes Verkuyl, dkk. Misi menurut Perspektif Alkitab. (Jakarta: Yayasan Komunikasi Bina Kasih, 2013). 38

33 Dr. Arie De Kuiper, Misiologia. (Jakarta: BPK Gunung Mulia, 2013) 18-19

${ }^{34}$ Arie De Kuiper, Misiologia..., 19-20
} 
Israel di antara segala bangsa merupakan suatu gambaran pemerintahan Allah dan suatu gambaran pelayanan selaku imam. Israel tak lain adalah suatu alat dalam tangan Tuhan, suatu tahap dalam rencana Allah. Yang dituju adalah keselamatan dunia. Pemilihan atas Israel adalah jalan yang ditempuh Allah untuk mencapai tujuan-Nya, yaitu pengakuan nama-Nya oleh sekalian bangsa. Penyelamatan Israel adalah persiapan untuk keselamatan bangsa-bangsa. ${ }^{35}$

Universalisme keselamatan dibentangkan pula dalam beberapa kitab lain seperti Rut, Yunus dan Yesaya (40-55). Dalam kitab Yunus dengan tegas menentang sikap partikularisme (pembatasan keselamatan itu kepada diri sendiri saja). Yunus (yang adalah orang Israel) dipanggil untuk menyatakan rahmat Allah terhadap Ninewe. Biarpun pemilihan atas Israel membawa penderitaan sampai maut sekalipun, tetapi justru itulah yang menjadi kesaksian tentang cinta kasih Allah. ${ }^{36}$

b) Aspek Eskatologi

Para nabi biasanya juga menyampaikan berita dari Allah kepada bangsabangsa. Seringkali mereka mengabarkan hukuman, baik kepada Israel maupun kepada bangsa-bangsa kafir, kadang hukuman atas Israel akan dilaksanakan oleh bangsa kafir, adakalanya hukuman atas bangsa-bangsa akibat sikap mereka terhadap (Allah) Israel, dan acapkali berita keselamatan untuk kedua-duanya; melihat keselamatan Israel, maka bangsa-bangsa akan mengetahui bahwa Aku, Tuhan, menguduskan Israel (Yeh. 37:28). ${ }^{37}$

Di dalam pemberitaan para nabi selalu saja ada pengharapan bahwa bangsabangsa lain akan ditarik menuju pusat kehadiran Allah Israel, lalu bangsa-bangsa lain itu akan mengaku nama-Nya. Keselamatan eskatologis digambarkan dalam PL melalui gambaran tentang datangnya berarakan bangsa-bangsa lain ke arah Sion. Kedatangan itu merupakan gerakan yang sentripetal (pusaran) menuju ke pusat dimana tersedia keselamatan, dimana ada Allah dan umat-Nya, pusat kehadiranNya, pusat dunia. Bangsa-bangsa akan datang kepada Israel dan Allahnya. Sion adalah ibu sekalian orang yang mengaku Allah selaku Bapa, bukan saja orang Israel, melainkan juga seluruh bangsa-bangsa. ${ }^{38}$

c) Aspek Masa Depan Mesianik

Di dalam pengharapan Israel akan masa depan, pemegang kunci ialah Almasih (Mesias) yang dijanjikan selaku pembawa keselamatan. Lebih tepat lagi: Ia merupakan poros berkisarnya masa depan. Yang dipentingkan dalam gambaran tentang zaman yang akan datang itu ialah pemerintahan Tuhan atas Israel dan atas

\footnotetext{
${ }^{35}$ Arie De Kuiper, Misiologia..., 20

${ }^{36}$ Ibid., 21

${ }^{37}$ Ibid., $21-22$

${ }^{38}$ Ibid., 22-23
} 
bangsa-bangsa lainnya, dan pemerintahan itu akan didatangkan dan dilaksanakan oleh oknum mesianis sebagai penyelamat. ${ }^{39}$

Kadang pengharapan mesianis berpaut pada orang yang diurapi Tuhan, baik dia memangku jabatan raja, maupun jabatan imam atau nabi. Perhatian khusus diberikan kepada hamba Tuhan yang menderita, seperti yang tampak dalam nyanyian-nyanyian Deutero-Yesaya (Yes 40-55), yakni pederitaan sengsara, masa depan mendekat hanyalah melalui sengsara, yang mendahului lahirnya zaman baru, yang diwakili oleh sisa-sisa setia, yang pada akhirnya diwakili oleh satusatunya hamba Allah yang taat dan setia. Hamba itu menggantikan sisa-sisa setia, dan sisa-sisa setia itu menggantikan umat Israel, dan umat Israel menggantikan bangsa-bangsa. Keselamatan yang dikaruniakan Tuhan kepada Israel mempunyai aspek universal, Israel yang dibaharui oleh karena diberi keadilan oleh Tuhan menjadi pembawa keselamatan sampai ke ujung bumi (Yes. 49:6). Dan kepada segala ujung bumi itu diserukan supaya mereka berpaling kepada Tuhan (Yes. $45: 22) .^{40}$

\section{Misi Dalam Perjanjian Baru}

Dari awal sampai akhir, Perjanjian Baru (PB) adalah kitab misi. Kitab ini lahir berdasarkan pekerjaan misi gereja-gereja Kristen awal, baik Yahudi maupun Yunani. Kitab-kitab Injil itu bagaikan rekaman langsung dari khotbah-khotbah missioner (Kis.5:32; 10:39), dan surat-surat PB bukanlah suatu bentuk apologetika untuk penginjilan, melainkan sarana pekerjaan misi yang aktual dan autentik. ${ }^{41}$ Titik tolak PB adalah pengharapan eskhatologis mengenai pertobatan bangsa-bangsa dan penyembahan mereka kepada Allah yang benar dan tunggal. Inti berita Injil adalah maklumat Yesus tentang Kerajaan sorga yang telah mendekat (Mat 4:17), sebab itu patutlah para pendengar bertobat. Berita itu dibawa khusus melalui para rasul kepada segala kaum Israel yang sesat (Mat.10:5-7).

Seluruh PB berbicara dalam bahasa penggenapan janji. Atas dasar pemberitaan Injil oleh Yesus sendiri, maka kita dapat mengatakan bahwa alasan adanya periode sementara antara kenaikan Yesus dan kedatangan-Nya kembali sebagai Anak Manusia adalah pekerjaan kerasulan Gereja di seluruh dunia. ${ }^{42}$ Injil merefleksikan sebuah periode gereja ketika orang Yahudi dan Kristen bukan Yahudi dengan kekuatan penuh memberitakan kabar baik. Injil menyuarakan panggilan kuat untuk mengkomunikasikan iman dalam Yesus sang Mesias kepada Israel dan bangsa-bangsa di muka bumi ini. ${ }^{43}$ Dengan sangat sederhana namun mendalam, misi merupakan hal yang untuknya komunitas Kristen diutus melakukannya, dimulai dari tempat di mana ia tinggal ("Kamu akan menjadi saksi-Ku di Yerusalem dan sampai ke ujung bumi", Kis. 1:8). Walaupun

\footnotetext{
${ }^{39}$ Arie De Kuiper, Misiologia..., Ibid., 24

${ }^{40}$ Ibid., 24-26

${ }^{41}$ John Stott, dkk. Misi menurut Perspektif Alkitab..., 68

42 Ibid., 70

${ }^{43}$ John Stott, dkk. Misi menurut Perspektif Alkitab..., 71
} 
dijalankan dengan berbagai cara sesuai keadaan setempat yang khas, keharusan misi adalah sama di manapun komunitas itu didirikan. ${ }^{44}$

\section{Misi Kerajaan Allah}

Berita sentral tentang Misi Allah yang terdapat dalam teks-teks Alkitab secara keseluruhan; Perjanjian Lama dan Perjanjian Baru, yaitu Kerajaan Allah, jadi Misi Allah itu adalah misi Kerajaan Allah. Misi Allah menurut Alkitab itu hanya satu, yaitu Missio Dei, yang sering disebut sebagai misi atau karya penyelamatan Allah bagi seluruh ciptaan-Nya. Penyelamatan Allah itu bersifat utuh dan menyeluruh, mencakup keselamatan pribadi dan sosial, meliputi keselamatan jasmani dan rohani, masa kini dan masa depan, dalam semua bidang kehidupan, menuju kepada pemulihan seluruh ciptaan Allah. ${ }^{45}$ Suatu proses yang konkret melalui kehidupan manusia yang diperbaharui dan hidup di bawah pemerintahan Allah. Tanda-tanda dari pemerintahan Allah atau sering disebut Kerajaan Allah adalah cinta kasih, kesejahteraan, keadilan, perdamaian, dan keutuhan ciptaan. Itulah sebabnya, Misi Allah juga dapat disebut sebagai misi Kerajaan Allah. ${ }^{46}$ Kerajaan Allah bukan wilayah atau teritori yang punya batas-batas, karena Kerajaan Allah meluas tanpa batas seperti karya Roh Kudus yang tidak dapat dibatasi oleh kelompok manusia mana pun. Sekarang ini sebagai gereja Yesus Kristus, Kerajaan Allah juga menjadi sumber dan dasar dari misi gereja di tengah-tengah masyarakat. Misi Kerajaan Allah yang luas dan mencakup semua bidang kehidupan manusia dan pemulihan seluruh ciptaan Allah. ${ }^{47}$

\section{Misi Integral}

Misi integral adalah Misi yang utuh, atau transformasi menyeluruh, adalah proklamasi dan perwujudan Injil/kasih Allah. Tidak hanya sekedar penginjilan dan keterlibatan sosial yang dilaksanakan berdampingan, tetapi dalam misi yang utuh, proklamasi memiliki konsekwensi sosial di saat gereja/orang kristen memanggil orang untuk bertobat dan mengasihi dalam segala aspek hidup. Keterlibatan sosial gereja/orang Kristen memiliki konsekwensi penginjilan karena kekristenan/gereja mengemban kesaksian atas anugerah Yesus Kristus yang membarui. Jika gereja/orang kristen mengabaikan dunia, sama dengan menghianati firman Allah yang telah mengutus gereja untuk melayani dunia. Jika gereja mengabaikan firman Allah, maka gereja tidak memiliki apapun untuk dibawa kepada dunia. ${ }^{48}$ Misi Integral ini adalah pelayanan yang kokoh dan terintegrasi, yaitu dengan memproklamasikan Kabar Baik dan sekaligus menunjukkan kasih Allah secara konkret dalam pergumulan bangsa dan dunia. ${ }^{49}$

\footnotetext{
${ }^{44}$ John Stott, dkk. Misi menurut Perspektif Alkitab..., 27

${ }^{45}$ Widi Artanto, Gereja dan Misi-Nya ..., 7

${ }^{46}$ Ibid., 7

${ }^{47}$ Ibid., 9

${ }^{48}$ John Ruck, dkk, Jemaat Misioner..., 313

${ }^{49}$ Ibid., 313-314
} 
Yesus Kristus dalam pelayanan-Nya selama berada di dunia, telah memberikan kehidupan baru dan damai yang datang dari surga kepada dunia. Ia bahkan bersedia membayar harga, dengan mati di salib. Melalui penumpahan darahnya, Kristus melakukan pendamaian atau rekonsiliasi antara kita dan Pencipta, dengan diri kita sendiri, dengan orang lain, dan dengan seluruh ciptaan-Nya. ${ }^{50}$ Selama pelayanan-Nya di dunia ini, Ia selalu menemui orang-orang yang berkekurangan secara rohani, sosial, politik dan fisik. Dapat dikatakan bahwa dalam pelayanan Yesus, Ia melihat penderitaan secara terintegrasi (fisik, sosial, politik dan rohani).

Pelajaran dan teladan yang Yesus Kristus tunjukkan yaitu, Ia melakukan pelayanan yang membumi; menjangkau orang-orang yang tidak memiliki pengharapan didunia ini dan membawa keadilan bagi mereka. ${ }^{51}$ Itulah sebabnya Ia merindukan agar pelayanan para murid-Nya melanjutkan apa yang telah Ia kerjakan, membawa damai sejahtera bagi dunia ini (Yoh. 20:21). Ini bukan pekerjaan mudah, karena itu Yesus menjanjikan akan mengaruniakan Roh Kudus yang akan mendampingi serta memampukan para murid-Nya menjadi saksi-saksi Allah bagi dunia (Kis. 1:8). Sejak saat itu Allah mengerjakan misi untuk dunia melalui gereja-Nya, membawa damai sejahtera bagi dunia dan membawa segala sesuatu tunduk di bawah ketuhanan Kristus (Ef. 1:9-10). ${ }^{52}$ Yesus mengajarkan para murid untuk mempunyai hati yang peduli terhadap orang-orang miskin, menderita, dan tertindas. Juga bagi gereja (umat Tuhan), harus memiliki hati yang peduli kepada kelemahan sesama, dan terlibat untuk menolong. Hambatan ketidakmampuan kita dalam berbagai hal tidak boleh mematikan langkah kita untuk menolong sesama, karena kita tidak mengerjakannya sendiri, melainkan bersama Dia, sumber segala rahmat dan berkat. ${ }^{53}$

Rasul Paulus yang giat dalam penginjilan, selalu memperhatikan orang-orang miskin, termasuk yang menderita kelaparan di Yerusalem. Dalam Galatia 2:10, Paulus berkata: “... hanya kami harus tetap mengingat orang-orang miskin dan memang itulah yang sungguh-sungguh hendak kulakukan". Ia mendorong warga jemaat dari berbagai tempat untuk memperdulikan dan menolong warga jemaaat miskin yang ada di Yerusalem. ${ }^{54}$

\section{Gereja}

Alkitab mengajarkan mengenai gereja dengan menggunakan beberapa ungkapan, yang ditunjukkan oleh Sunand Sumithra dalam bukunya Holy Father: A Doxological Perspective on Systematic Theology, yang dikutip oleh Stevri I Lumintang, bahwa gereja adalah:

Pertama, Umat Allah yang baru, kepunyaan Allah dalam hubungan dengan Dia, melalui anugerah dan iman (Rm. 9:24, 11:16); Kedua, Israel yang benar, bukan melalui

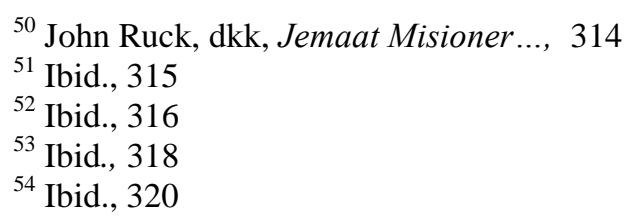


kelahiran lahiriah, melainkan karena kelahiran oleh iman, yang mengklaim janji Allah kepada Abraham, Bapa dari segala orang beriman (FLP.33; Kol. 2:11; Gal. 3:7); Ketiga, rumah Allah, dimana Allah diam, baik secara pribadi maupun secara persekutuan, (I Kor. 3:17, 6:12); Keempat, suatu persekutuan, koinonia, yang lebih dari persahabatan manusia dan sesungguhnya adalah suatu persekutuan sorgawi (Kis. 2:42); Kelima, orang percaya, mereka yang memanggil nama Yesus (Rm.10:11); Keenam, Tubuh Kistus, yang paling sering digunakan oleh Paulus untuk menerangkan tentang keunikan gereja, yang tidak mungkin ada tanpa Kristus sebagai Kepalanya (Ef. 4:15; Kol.1:18); Ketujuh, suatu bangunan Allah (I Kor. 3:9,16); Kedelapan, Tentara Allah (I Tim. 2:3)

Dean S. Gililand dalam buku Pauline Theology san Mission Practice menggambarkan bahwa gereja adalah suatu umat, yaitu suatu umat yang bersekutu , suatu umat yang bersaksi, satu tubuh umat Allah. Tubuh itu adalah suatu organisme yang hidup, yakni suatu persekutuan orang-orang yang hidup, serta diberi hidup oleh sumber hidup gereja yakni Roh Kudus. ${ }^{56}$

Orang Kristen mula-mula memahami bahwa gereja adalah sebagai umat Allah yang baru, yang dipilih di dalam Yesus untuk kehidupan yang kekal. unsur yang mendasar dari konsep gereja adalah, bahwa gereja sebagai jemaat murid-murid Tuhan. Dan bagi para rasul, gereja merupakan suatu persekutuan orang percaya. Ada pun pengertian gereja sebagai berikut:

\section{Pengertian Gereja secara Teologi Sistematika}

Untuk memahami tentang arti Gereja melalui pendekatan teologi sistematika, maka EkkleVision Media Centre dalam buku 'Gereja' membedakannya dalam beberapa segi sbb:

1.) Segi Obyektif/Organisasi. Dalam segi ini, gereja dilihat sebagai sebuah tempat dimana manusia bertemu dengan keselamatan yang diberikan oleh Allah kepadanya di dalam Yesus Kristus. Gereja adalah sebuah lembaga atau institusi yang mengantar manusia untuk menerima keselamatan.

2.) Segi Subyektif/Jemaat. Gereja juga adalah persekutuan orang-orang percaya yang ingin beribadah kepada Allah. Gereja adalah juga ungkapan iman orang-orang percaya, suatu persekutuan yang dibentuk manusia untuk bersama-sama bertumbuh dalam iman dan hidup dalam persekutuan yang erat dengan Allah.

3.) Segi Apostolik/Penginjilan. Gereja adalah persekutuan orang percaya yang diutus untuk mengantar keselamatan dari Allah kepada dunia. Dengan demikian maka gereja merupakan buah sulung dari tuaian ilahi, yaitu menjadi ciptaan baru. Gereja adalah sarana dari Allah untuk memberitakan Injil keselamatan bagi dunia ini. ${ }^{57}$

\footnotetext{
${ }^{55}$ Stevri I. Lumintang, Misiologia Kontemporer..., 117

${ }^{56}$ Ibid., 118

57 __ Gereja, (Jakarta: EkkleVisio Media Centre), 2-3
} 


\section{Gereja Menurut Perjanjian Lama}

Pengertian gereja sudah muncul dalam Perjanjian Lama yang dikenal dengan perkumpulan jemaat (Kel. 12:6; Bil. 14:5; Yeremia 26:17). Dalam Perjanjian Lama, gereja sebagai Umat Allah, berakar pada Israel sebagai umat pilihan Allah.

Perjanjian Lama memakai dua istilah untuk menunjuk Gereja, yaitu qahal (atau kahal), yang di turunkan dari akar kata yang sudah tidak dipakai lagi yaitu qal (atau kal), yang artinya "memanggil"; dan 'edhah yang berasal dari kata ya'adh yang artinya "memilih" atau "menunjuk" atau "bertemu bersama-sama di satu tempat yang telah ditunjuk" ${ }^{58}$ Kata "Edhah sebenarnya berarti berkumpul karena sudah ada perjanjian, dan jika kata itu diterapkan pada bangsa Israel, maka kata itu menunjuk pada masyarakat bangsa itu sendiri, yang dibentuk oleh anak-anak Israel atau oleh kepala perwakilan mereka, baik bergabung bersama maupun tidak. Sedang kata Qahal dengan tepat menunjukkan arti yang sesungguhnya dari pertemuan bersama satu umat. ${ }^{59}$

Israel disebut "Qahal" dalam Keluaran 12:6, kata itu menyangkut orang-orang yang berkumpul untuk tujuan-tujuan keagamaan. Dalam bahasa Yunani kata qahal diterjemahkan dengan kata ekklesia, yang dikenal di Indonesia sebagai gereja/jemaat. Kitab Perjanjian Lama sebagai latar belakang gereja menunjuk kepada sifat keagamaannya, Israel memiliki Bait dan imamat, hari-hari puasa dan perayaan, sehingga merupakan suatu gereja. ${ }^{60}$ Dalam rencana dan maksud Allah, Israel selalu bertanggung jawab untuk menyampaikan kabar tentang kasih karunia Allah kepada bangsa-bangsa lain. Israel dimaksudkan sebagai bangsa yang menyampaikan Firman. ${ }^{61}$

Gereja dibangun diatas kesaksian Perjanjian Lama dan Perjanjian Baru. Gereja tidak hanya berdiri diatas kesaksian para murid, tetapi juga diatas nabi terdahulu, serta diatas pekerjaan nubuatan dan kesaksian para nabi (1 Petrus 1:10-11; Efesus 2:19-22, 4:11-16).

\section{Gereja Menurut Perjanjian Baru}

Perjanjian Baru juga memiliki dua kata yang diambilnya dari Septuaginta, yaitu ekklesia yang berasal dari kata - ek dan kaleo, yang artinya "memanggil ke luar", dan kata sunagoge, dari kata sun dan ago yang berarti " datang atau berkumpul bersama". Kata sunagoge ini secara eksklusif menunjuk kepada arti pertemuan ibadah orang Yahudi atau bisa menunjuk kepada arti bangunan di mana mereka berkumpul untuk beribadah secara umum. ${ }^{62}$

\footnotetext{
${ }^{58}$ Louis Berkhof, Teologi Sistematika 5 - Doktrin Gereja (Surabaya: Momentum, 2001), 5

${ }^{59}$ Ibid., 5

${ }^{60}$ Martin B. Dainton, Gereja dan Bergereja, apa dan bagaimana? (Jakarta: Yayasan Komunikasi Bina Kasih, 2002), 25

${ }^{61}$ John Stott, dkk. Misi menurut Perspektif Alkitab..., 38

${ }^{62}$ Louis Berkhof, Teologi Sistematika..., 6 
Dalam Perjanjian Baru, istilah ekklesia secara umum menunjuk kepada Gereja, walaupun dalam beberapa bagian kata itu sekedar menunjukkan pertemuan secara umum (Kis. 19:32,39,41). ${ }^{63}$

Tuhan Yesus adalah yang pertama kali memakai kata ekklesia dalam Perjanjian Baru, dan Ia memakai kata itu untuk menunjuk murid-murid yang ada bersama dengan Dia melalui perkataan dalam Matius 16:18 “...dan di atas batu karang ini Aku akan mendirikan jemaat-Ku dan alam maut tidak akan menguasainya”. Mereka adalah ekklesia dari Mesias, Israel yang sejati.

Kata Jemaat disini dapat kita pahami sebagai Gereja, karena dalam bahasa aslinya yakni bahasa Yunani, kata "Jemaat" ditulis dengan kata "Ekklesia" yang menjadi asal kata "igreja" (bahasa Portugis) yang kemudian dalam bahasa Indonesia menjadi "Gereja".

Rasul Paulus juga menggunakan kata "Ekklesia" dalam menyebut jemaat-jemaat Allah, baik itu di Korintus, Efesus, Roma, dll. Hal ini kembali menunjukkan bahwa, arti gereja menurut Perjanjian Baru adalah sebagai suatu Sidang Allah. Dalam Perjanjian Baru, Gereja juga memiliki beberapa arti selain sebagai sidang/jemaat, yakni: sebagai Tubuh Kristus (Roma 12:5), sebagai Mempelai Kristus (Efesus 5:22), sebagai Kawanan Domba Allah (Yohanes 10:22), sebagai Bait Allah (1 Petrus 2:5), sebagai Pohon Anggur dan rantingnya (Yohanes 15:1). ${ }^{65}$

Dari arti-arti tersebut di atas, dapatlah dikatakan bahwa gereja bukan suatu benda atau tempat, tapi gereja menurut Perjanjian Baru adalah sebagai sosok pribadi kolektif, suatu Sidang atau Jemaat, suatu persekutuan. Perlu diperhatikan unsur-unsur penting yang menandai persekutuan orang Kristen, yaitu adanya persatuan dan kesatuan antara anggota-anggota gereja dengan kepalanya yaitu Kristus, yang erat hubungannya dan Kristuslah yang menjadikan gereja itu, dan hanya Dia yang mengambil prakarsa untuk membangun gereja.

\section{Fungsi Dan Tugas Gereja}

Gereja pada awalnya adalah suatu pertemuan atau persekutuan jemaat mula-mula, dimana didalam pertemuan atau persekutuan tersebut, mereka berusaha menjaga kekudusan hidup mereka dengan menekuni ajaran Tuhan Yesus Kristus, dengan bimbingan para Rasul. Fungsi gereja sendiri ditentukan oleh Sang Pemilik gereja, sosok yang telah memanggil keluar dari kegelapan kepada terang-Nya, yakni Allah didalam Yesus Kristus sebagai kepala, dan gereja adalah tubuh-Nya (1Korintus 12:27). Jadi sebagai tubuh, gereja tentu memiliki fungsi dan tugas yang telah ditentukan oleh pemilik tubuh yaitu Yesus Kristus, yang juga telah mengemban tugas dari Allah Sang Pencipta (Yohanes 20:21). Jadi tugas yang diberikan Yesus Kristus kepada gereja merupakan tugas estafet yang telah lebih dahulu dikerjakan oleh-Nya. ${ }^{66}$

\footnotetext{
${ }^{63}$ Ibid., 7

${ }^{64}$ Martin B. Dainton, Gereja dan Bergereja..., 10

${ }^{65}$ Ibid., 71-74

${ }^{66}$ Y. Tomatala, Teologi Misi..., 78
} 
Gereja yang adalah kumpulan para pengikut Kristus (orang Kristen) melakukan persekutuan untuk menjaga kekudusan hidup mereka dalam menekuni ajaran Kristus, terus bertekun dan bersaksi tentang kehidupan Kristus yang telah memberi mereka keselamatan dari kehidupan yang fana. Itu sesuai dengan mandat yang diberikan oleh Yesus Kristus kepada para Rasul-Nya, yakni Amanat Agung, yang merupakan tugas esensial gereja, klimaks dari pengajaran Yesus.

Amanat Agung atau Perintah Agung ini bukanlah milik khusus salah satu Negara, budaya atau orang-orang tertentu. Menurut Keith E. Brown ada tiga sebab, yaitu:

1) Amanat Agung (Mat. 28:19-20; Mark. 16:15; Luk. 24:47; Yoh. 20:21; Kis. 1:8) adalah berbentuk perintah, yang maksudnya untuk ditaati oleh siapa saja atau semua orang yang mengaku setia mengikuti Yesus Kristus sebagai Juru Selamat dan Tuhannya.

2) Ditujukan bagi semua orang Kristen, pada setiap saat, di semua tempat, dan untuk semua usia.

3) Tidak ada pengecualiaan bagi orang-orang tertentu atau kelompok-kelompok tertentu untuk tidak menurutinya. Tidak ada pengecualian, karena setiap orang percaya dengan tidak memandang Negara asalnya, atau apa pekerjaannya, diperintahkan supaya terlibat memenuhi Amanat Agung Tuhan Yesus. ${ }^{67}$

Stevri I. Lumintang, juga mengemukanan tiga aspek yang penting dari Amanat Agung Tuhan Yesus, yaitu:

1) Amanat Agung adalah Mandat Otoritatif. Tuhan Yesus berkata: "Semua kuasa di surga dan di bumi telah diberikan pada-Ku." Pernyataan ini menjelaskan kekuasaan Yesus atas seluruh dunia, dan merupakan jaminan yang kuat mengenai misi Yesus yang tidak mungkin gagal. Otoritas Yesus ini juga menjadi jaminan bagi misi gereja sebagai pelaksana Amanat Agung, amanat yang berotoritas dari Yesus. Sehingga otoritas misi gereja dalam dunia ini adalah bergantung pada otoritas Yesus. Tidak ada wilayah dan penghuninya di dunia ini yang tidak berada di bawah otoritas Yesus dan gereja-Nya. ${ }^{6}$

2) Amanat Agung adalah Mandat Pemuridan. Berdasarkan teks, pertama-tama Yesus berkata: "karena itu pergilah" (Poreuthentes) yang berarti berangkatlah, atau pergi meninggalkan, melintasi batas sosial, rasial, kultural, geografis. Dari arti ini, maka misi Yesus adalah misi yang bersifat inklusif, misi yang terbuka untuk semua orang tanpa mengenal latar belakang apapun. Inti Amanat agung ialah memuridkan semua bangsa. Inti teks yang membahas mengenai amanat ini adalah "menjadikan murid" artinya menjadikan semua orang di mana pun mereka berada dan siapapun mereka untuk mengikuti Yesus. ${ }^{69}$

3) Amanat Agung adalah mandat yang mendesak. Dalam amanat-Nya, Yesus memberikan janji yang berbunyi: "Aku menyertai kamu senantiasa sampai kepada akhir zaman." Yesus menjanjikan untuk menyertai gereja-Nya sepanjang masa.

\footnotetext{
${ }^{67}$ Keith E. Brown. Pelayanan Misi dalam Gereja-gereja Lokal di Asia..., 1-2

${ }^{68}$ Stevri I Lumintang, Misiologia Kontemporer..., 112

${ }^{69}$ Stevri I Lumintang, Misiologia Kontemporer..., 113
} 
Yesus sedang mendesak gereja-Nya untuk menyelesaikan panggilan misinya, bersamaan dengan Yesus menghantar gereja-Nya kepada tujuan akhir. ${ }^{70}$

Akhirnya, arti Amanat Agung yang ditugaskan kepada gereja masa kini, seperti yang dikemukakan oleh Wilbert R. Shenk, yang dikutip dalam buku Misiologia Kontemporer, yaitu:

Pertama, amanat Agung adalah proyek Allah untuk suatu dunia yang baru, suatu ciptaan yang baru Itu merupakan mandat Yesus untuk gereja-Nya yang adalah saksi kuasa kebangkitan-Nya kepada semua orang diseluruh dunia sampai pada akhir zaman; Kedua, amanat Agung tidaklah dilaksanakan secara legalistik. Roh Kudus sebagai dinamisator misi, menghidupkan dan menguasai umat Allah untuk menjadi suatu komunitas missioner; Ketiga, Amanat Agung meluaskan pelayanan dan kesaksian mengenai Yesus Kristus. ${ }^{71}$

Inilah yang harus dilakukan gereja, bersaksi tentang Injil yang adalah 'kabar baik', kabar penebusan yang dilakukan Yesus Kristus atas dosa-dosa manusia, dan janji hidup kekal yang akan diberikan oleh Allah bagi yang percaya kepada Yesus Kristus. Allah mengharapkan jauh lebih banyak dari setiap orang Kristen. Ia mengharapkan setiap orang Kristen menggunakan karunia dan talentanya dalam pelayanan. ${ }^{72}$

Dalam pelayanan gereja masa kini, ada tiga tugas gereja yang sering juga disebut sebagai trilogi/tritugas Gereja, yang menjadi landasan pelayanan misi gereja, yaitu:

\section{Koinonia (Persekutuan)}

Persekutuan adalah "Hakikat" yang sudah diletakkan oleh Yesus Kristus, bukan tujuan yang masih harus dikejar atau diusahakan manusia. Manusia hanya tinggal bersedia menerima, masuk dan menjalankan serta melaksanakannya. Bila persekutuan tidak dapat diwujudkan, maka bisa menjadi penghalang, kendala, batu sandungan bagi dunia untuk percaya kepada Yesus Kristus. ${ }^{73}$

Allah menjadikan gereja sebagai suatu persekutuan yang mengaku satu tubuh, satu Roh dalam ikatan damai sejahtera, satu pengharapan, satu Iman, satu Baptisan, satu Tuhan, satu Allah dan Bapa dari semua (Efesus 4:4-6). Di dalam persekutuan umat ini, Roh Allah bekerja untuk memungkinkan terjadinya integrasi manusia yang beriman, karena Allah hadir dan menyembuhkan hubungan yang rusak antara umat-Nya dengan diri-Nya. $^{74}$

Persekutuan orang percaya adalah persekutuan yang dilandasi oleh Kasih Allah, dan sebagai persekutuan kasih, maka gereja adalah keluarga dan kawan sekerja Allah (Efesus 2:19 ; 1 Korintus 3:9a) yang dituntut untuk ada didalam kasih, sehati sepikir, dalam satu tujuan dengan tidak mencari kepentingan sendiri tetapi juga untuk

\footnotetext{
${ }^{70}$ Ibid., 114

${ }^{71}$ Stevri I Lumintang, Misiologia Kontemporer..., 114-115

${ }^{72}$ Rick Warren, The Purpose Driven Church, (Malang: Gandum Mas, 2016), 373

${ }^{73}$ Stevri I. Lumintang, Misiologia Kontemporer..., 213

${ }^{74}$ Eli Tanya, D.Th. Gereja dan Pendidikan Agama Kristen..., 7
} 
kepentingan orang lain juga, sehingga anggota yang satu memandang anggota yang lain lebih utama daripada dirinya sendiri (Filipi $2: 1-4){ }^{75}$

\section{Marturia (Kesaksian)}

Marturia adalah kata bahasa Yunani yang mempunyai sangkut paut dengan "Martir", yang mengacu kepada kesaksian tentang Injil Yesus Kristus. Itu berarti tugas gereja: pertama, gereja harus memberitakan Injil, tentang Allah di dalam Yesus Kristus yang berlaku adil dan benar yang menyelamatkan (Bdk. Roma 1:16-17 ;Lukas 2;18-19) yang menuntut pertobatan yang mengaruniakan pengampunan dosa dan keselamatan, yang memberi keadilan kepada orang-orang miskin dan tertindas, yang mengaruniakan kesejahteraan kepada segala bangsa, kepada segala makhluk, sebagai bagian dari karya keselamatan Yesus Kristus. (Lukas24:47; Markus 16:15). kedua, gereja harus memberitakan Injil kepada semua makhluk di seluruh dunia sampai ke ujung bumi dan sampai kepada akhir zaman (Bdk. Matius 28:18-20; Markus 16:15; Kolose1:23). Kesaksian dan pekabaran Injil adalah panggilan bagi orang percaya sebagai gereja-Nya kepada dunia. ${ }^{76}$ Selanjutnya, gereja harus mencamkan bahwa bersaksi itu melibatkan seutuh kehidupan warga gereja, lahir batin, tidak cukup dengan kata-kata. Bersaksi berarti menunjukkan kasih Allah di dalam Yesus Kristus.

\section{Diakonia (Pelayanan)}

Kata Diakonia berasal dari bahasa Yunani "Diakoneo" dari kata kerja "Diakonein" yang berarti melayani di meja makan dan memperhatikan agar persediaan mencukupi. Jadi "Diakonos" berarti melaksanakan tugas-tugas pelayanan, baik di meja perjamuan maupun tugas-tugas sosial lainnya (Bdk. 1Kor. 11:20-22; Kis. 2:44-46). Gereja tidak bisa dipahami keberadaannya tanpa diakonia. Pelayanan gereja didasar oleh pelayanan Yesus Kristus sendiri. Alkitab menyatakan bahwa Dia telah memberikan nyawanya sebagai tebusan bagi banyak orang (Markus 10:45; Filipi 2:6-8). Karena itu pelayanan diakonia sosial juga adalah wujud pelayanan gereja yang peduli melibatkan diri untuk melayani sesama.

Melayani berarti mewujud nyatakan kasih Allah itu kepada sesama, yakni: (1) Gereja harus bercahaya di tengah-tengah dunia - Filipi 2:15. (2) Gereja harus menjadi terang yang terbuka bagi semua orang - Mat. 5:14-16. (3) Gereja harus selalu siap membawa orang lain kepada Kristus. 1 Petr. $3: 15 .^{78}$

Dalam hal inilah gereja hadir untuk memberi pertolongan dan membawa orangorang yang miskin, menderita, lemah, terlantar, terasing, tersisihkan, orang-orang yang masih dalam kebodohan, korban bencana alam, korban peperangan, korban ketidak pastian hukum. Pelayanan diakonia sosial hendaknya dilakukan dengan kerelaan dan kesediaan serta ketulusan hati untuk memberi, sehingga pelayanan sosial dapat

\footnotetext{
${ }^{75}$ Sih Budidoyo, Kesalehan Sosial..., 213-215

${ }^{76}$ Sih Budidoyo, Kesalehan Sosial..., 216-218

${ }^{77}$ Ibid.

${ }^{78}$ gkiiubud.blogspot.co.id. diakses tgl. 12 November 2017 pkl. 21.00.
} 
diwujudkan dengan semangat yang kuat untuk menanggung yang lemah, yang kaya mencukupkan yang miskin seperti halnya yang telah dilakukan oleh jemaat gereja mulamula (Kis. 2:45). ${ }^{79}$

Gereja ada seutuhnya untuk tujuan-tujuan yang dimaksudkan Allah ketika Ia menciptakannya. Oleh sebab itu, gereja tidak mempunyai kebebasan untuk mengarang agendanya sendiri. Ia merupakan suatu komunitas dalam respons terhadap Missio Dei, yang memberikan kesaksian tentang kegiatan Allah di dunia melalui pemberitaan kabar baik mengenai Yesus Kristus dalam ucapan dan tindakan. ${ }^{80}$ Yaitu: Ada kisah tentang Yesus yang selalu harus diceritakan kembali sebagai penggenapan janji Allah untuk "memulihkan segala sesuatu" (Kis. 3:21; Ef. 1:10). Ada berita tentang komunitas rasuli yang menceritakan "perbuatan-perbuatan besar yang dilakukan Allah" (Kis. 2:11) dan menggariskan rincian praktis dari kehidupan yang telah ditebus. Ada kehidupan ibadah jemaat yang berpusat pada puji-pujian dan ucapan syukur. Disini Gereja mengakui pencipta keberadaannya dan kehidupannya, dan mengingatkan dirinya " bahwa ia hidup oleh anugerah yang mengagumkan dari kemurahan hati yang tak terbatas. ${ }^{81}$

Pemahaman diri gereja dan rasa jati dirinya (eklesiologinya) terkait erat dengan panggilannya untuk membagi dan menghayati Injil Yesus Kristus sampai ke ujung bumi dan sampai akhir zaman. Tanpa rasa panggilan yang kuat terhadap pekerjaan misionernya, gereja tidak dapat menganggap dirinya bersifat am atau bersifat rasuli. ${ }^{82}$ Itulah sebabnya, gereja harus berjuang untuk menjadi gereja yang bersifat missioner, gereja missioner yang setia ikut melaksanakan misi Allah di dunia ini, sehingga kalau gereja berhenti bersifat missioner, ia tidak sekadar gagal dalam salah satu tugasnya, lebih daripada itu ia telah berhenti menjadi gereja.

\section{Pemberdayaan Jemaat}

Jemaat adalah komunitas yang disatukan dalam Kristus, sehingga tidak ada lagi tembok pemisah ataupun diskriminasi berdasarkan suku, keluarga, status sosial, jenis kelamin, pendidikan, kemampuan, dan sebagainya. Maka seluruh jemaat dalam Tuhan berfungsi untuk melayani dan bersaksi. ${ }^{83}$

Hendrik Kraemer dalam buku Jemaat Misioner, menekankan bahwa jemaat, selain mencerminkan sifat-sifat Kristus sebagai nabi, imam dan raja, mempunyai hakikat yang sangat mendasar, yang berakar pada diri Kristus, yaitu pelayanan. Jemaat adalah pelayanan, jemaat adalah diakonia, jemaat berada untuk dunia, jemaat adalah misi. ${ }^{84}$

Dalam setiap implementasi misi gereja, aspek partisipasi atau peranan anggota jemaat sangat menonjol, karena di dalam kehidupan jemaat di tengah-tengah masyarakat, misi Allah itu dapat diwujudkan. Maka pemimpin gereja dalam melayani

\footnotetext{
${ }^{79}$ Sih Budidoyo, Kesalehan Sosial..., 219

${ }^{80}$ J. Andrew Kirk, Apa Itu Misi?..., 37

${ }^{81}$ Lesslie Newbigin, The Gospel in a Pluralist Society (London, SPCK, 1989) 151

${ }^{82}$ J. Andrew Kirk, Apa Itu Misi?..., 36

${ }^{83}$ John Ruck, dkk, Jemaat Misioner..., 239

${ }^{84}$ Ibid., 140
} 
jemaat harus mengajarkan agar jemaat itu sendiri secara aktif dan kreatif menjadi pelaksana misi gereja, melalui pembinaan, pelatihan dan pendampingan, yang sering disebut sebagai pengaderan. Pengaderan warga gereja perlu dikembangkan dengan dasar teologi misi yang relevan dan kontekstual berdasarkan Alkitab agar jemaat dapat menjadi penampakan gereja yang paling konkret di dunia.

Beberapa cara memberdayakan jemaat secara praktis, yang bisa diterapkan, yaitu:

\section{Pembinaan Warga Gereja}

Pembinaan waga gereja adalah usaha melengkapi gereja dan anggota-anggota gereja dalam kepercayaan dan pengakuannya menjadi anggota masyarakat yang bertanggung jawab, sebagai jalan dan proses untuk melengkapi manusia. Dengan kata lain akan membantu orang dalam melengkapi dirinya bagi pelayanan. Dasarnya yaitu Efesus 4:11-16, yang berbunyi, "Dan Ialah yang memberikan baik rasul-rasul maupun nabi-bani, baik pemberita-pemberita Injil maupun gembala-gambala dan pengajarpengajar untuk melengkapi orang-orang kudus bagi pekerjaan pelayanan, bagi pembangunan tubuh Kristus". ${ }^{85}$ Jadi pembinaan adalah memuridkan mereka sampai dewasa melalui pelayanan Firman dan penyerahan diri dalam segala aspek kehidupan, untuk mengikuti Tuhan Yesus, dan berusaha mengenal karunia dan berkat mereka agar dapat melayani menurut talenta dan kemampuannya. ${ }^{86}$

\section{Pelatihan Warga Gereja}

Warga jemaat yang telah dimobilisasi itu perlu diperlengkapi melalui pelatihan. Dalam pelatihan diberi pengajaran dan mentoring kepada mereka, termasuk pengertian praktis tentang pelayanan misional di dunia melalui pekerjaan ataupun profesi, berperan dalam masyarakat majemuk, serta memberi kesaksian pribadi, untuk menceritakan cerita-cerita dari Alkitab dan untuk menyampaikan pesan Injil Kristus dalam cara yang sesuai dengan konteks lingkungan mereka, dengan pendekatan yang cocok untuk setiap situasi. Membentuk tim-tim pelayanan di mana talenta masing-masing saling mengisi dan saling mendukung. Memberi visi, kreatifitas, dan komunikasi yang baik, serta inisiatif-inisiatif baru dalam jemaat agar menuju pelayanan misional, di bawah pimpinan Tuhan yang terus digumuli dalam doa. ${ }^{87}$ Pelatihan dapat diberikan oleh lembaga berpengalaman untuk memperlengkapi warga jemaat bagi pelayanan. ${ }^{88}$

\section{Pendampingan Bagi Warga Gereja}

Pendampingan yaitu suatu kegiatan menolong yang karena sesuatu sebab butuh didampingi. Karena setelah mereka mengenal karunia dan bakat mereka, dan dilatih tentang pelayanan, maka selanjutnya memberi kesempatan-kesempatan melayani

\footnotetext{
${ }^{85}$ Eli Tanya, D.Th. Gereja dan Pendidikan Agama Kristen ..., 143

${ }^{86}$ John Ruck, dkk, Jemaat Misioner..., 251

${ }^{87}$ John Ruck, dkk, Jemaat Misioner..., 251-252

${ }^{88}$ Ibid., 410
} 
menurut talenta dan kemampuan. Dimulai dengan tanggung jawab dan pelayanan yang relatif kecil, supaya talenta dan kemampuannya dapat diuji dan melalui pengalaman. ${ }^{89}$

Semua yang diperlukan agar gereja bertumbuh sudah disediakan Allah. Agar pertumbuhan jemaat dan tugas misinya dapat dijalankan, maka keseluruhan anggota jemaat perlu dilibatkan. Bilamana seluruh warga jemaat dimobilisasi bagi misi, maka akan ada perubahan signifikan. Setiap orang Kristen harus mengerti bahwa dia adalah saksi Kristus dan bahwa tempat kerja adalah "ladang pelayanan"nya yang diberikan oleh Tuhan. $^{90}$

Orang Kristen yang melayani Allah sesuai dengan karunia dan panggilannya akan sanggup memenuhi tanggung jawabnya dengan antusiasme yang jauh lebih besar dibandingkan dengan orang yang sekadar melakukan tugasnya. Bagi banyak orang Kristen, penemuan karunia ini merupakan pengalaman penting kerohanian mereka. Jadi, mereka menerima kesadaran rohani baru yang diberikan Allah dan yang secara positif mempengaruhi semua bidang kehidupan mereka. ${ }^{91}$

Tuhan Yesus mengharapkan agar pengikut-pengikut-Nya secara wajar dan atas inisiatif sendiri memberitakan Injil-Nya diantara masyarakat sekitar daerah mereka, kemudian ke seluruh kota, juga ke kota-kota yang berdekatan dengan mereka dan selanjutnya sejaumana mereka mampu pergi. ${ }^{92}$ Sebagian besar gereja mempercayai konsep bahwa setiap anggota adalah pelayan, bahkan banyak yang menekankan hal itu dalam khotbah dan ajaran, sayangnya sebagian anggota tidak melakukan apa-apa, hanya hadir dan memberi. Maka gereja jangan sekali-kali berhenti mengajarkan tentang pentingnya setiap orang Kristen memiliki pelayanan. ${ }^{93}$ Gereja membutuhkan sistem terencana yang teratur baik untuk menemukan, mengarahkan, serta mendorong anggotanya. Gereja juga harus mengadakan proses untuk memimpin orang-orang kepada komitmen yang sungguh-sungguh dan pelayanan yang lebih besar bagi Kristus.

Gereja dapat berfungsi sesuai dengan rencana Allah hanya jika hidup dalam simbiosis sebagai satu tubuh dengan banyak anggota yang saling melengkapi. Kekristenan menghargai keberagaman, karena setiap orang mempunyai karunia yang berbeda. Dalam perbedaan ini mereka bekerja sama dan saling membangun. ${ }^{94}$

Jadi mengapa Tuhan Yesus menginginkan gereja-Nya melakukan semua itu? karena kebanyakan manusia di dunia ini belum mendengar tentang Dia, dan mereka adalah yang terhilang. Karena itu, Dia ingin gereja-Nya membawa berita-Nya ke ujungujung bumi.

\footnotetext{
${ }^{89}$ Ibid., 252

90 John Ruck, dkk, Jemaat Misioner..., 413-415

${ }^{91}$ Christian A. Schwarz dan Christoph Schalk, Pertumbuhan Gereja Alamiah. (Metanoia Publising, 2002), 64

${ }^{92}$ Keith E. Brown. Pelayanan Misi..., 8

${ }^{93}$ Rick Warren, The Purpose Driven Church ... , 375

${ }^{94}$ Christian A. Schwarz, Pertumbuhan Gereja Alamiah..., 167
} 


\section{DAFTAR PUSTAKA}

Michael L. Cooper White,

2009 "Christian Stewardship In The Light Of A Theology Of The Cross". Dialog : A Journal of Theology.

Richard B. Cunningham,

1989 Creative Stewardship. Nashville: Abingdon Press.

M.S. Anwari,

2002 Peranan Penatalayanan Dalam Pengembangan Jemaat. Malang:

Gandum Mas.

Keith E. Brown,

1999 Pelayanan Misi Dalam Gereja-Gereja Lokal di Asia. Batu: Departemen Misi YPPII.

Widi Artanto,

2016 Gereja dan Misi-Nya. Yogyakarta: Yayasan Taman Pustaka Kristen Indonesia.

Y. Tomatala,

2003 Teologi Misi. Jakarta: YTb Leadership Foundation.

David J. Bosch, 1997 Trasformasi Misi Kristen. Jakarta: BPK Gunung Mulia.

John Ruck, dkk,

2011 Jemaat Misioner. Jakarta: Yayasan Komunikasi Bina Kasih.

2012 Kamus Besar Bahasa Indonesi, Pusat Bahasa. Jakarta: PT. Gramedia Pustaka Utama.

John Stott, Johannes Verkuyl, dkk.

2013 Misi menurut Perspektif Alkitab. Jakarta: Yayasan Komunikasi Bina Kasih.

Dr. Arie De Kuiper,

2013 Misiologia. Jakarta: BPK Gunung Mulia. 
Louis Berkhof,

2001 Teologi Sistematika 5-Doktrin Gereja. Surabaya: Momentum.

Martin B. Dainton,

2002 Gereja dan Bergereja, apa dan bagaimana? Jakarta: Yayasan Komunikasi Bina Kasih.

Rick Warren,

2016 The Purpose Driven Church. Malang: Gandum Mas.

Lesslie Newbigin, 1989 The Gospel in a Pluralist Society. London, SPCK

Christian A. Schwarz dan Christoph Schalk, 2002 Pertumbuhan Gereja Alamiah. Metanoia Publising. 